\title{
Apoptotic functions of microRNAs in pathogenesis, diagnosis, and treatment of endometriosis
}

\author{
Mona Taghavipour ${ }^{1}$, Fatemeh Sadoughi ${ }^{2}$, Hamed Mirzaei ${ }^{2}$, Bahman Yousefi ${ }^{3}$, Bahram Moazzami ${ }^{4}$, \\ Shahla Chaichian ${ }^{4 *}$, Mohammad Ali Mansournia ${ }^{5}$ and Zatollah Asemi2 ${ }^{2^{*}}$
}

\begin{abstract}
MicroRNAs or miRNAs are a component of the non-coding RNAs family which is engaged in many cellular functions such as cell proliferation, apoptosis, gene expression, signaling pathways, angiogenesis, and etc. Endometriosis is a malignant gynecologic disorder occurring in women before menopausal age. Pathogenesis of this illness is still a discussion subject between the scientists but in our knowledge, microRNAs can be one of the possible involved factors. The purpose of this paper is to investigate the role of apoptotic activities of miRNAs in endometriosis. Accumulative evidence has demonstrated the role of cell proliferation, apoptosis, and invasion in the progression of these diseases. In this review, we looked into the specific role of apoptosis and its related genes and pathways in endometriosis and tied to present an explanation of how miRNAs can affect endometriosis by their apoptotic activities. What we found is that a great extent of miRNAs is involved in this illness and they are responsible for repressing apoptosis and progression of the disease. As a result, miRNAs have two different usages in endometriosis: biomarkers and potential therapeutic targets. In this review we gathered a great amount of evidence to inquire into the role of micro RNAs in inducing apoptosis and how this mechanism can be exerted for therapeutic purposes for endometriosis.
\end{abstract}

Keywords: Apoptosis, miRNA, Endometriosis, BCL-2, BAX

\section{Background}

Generally, RNAs which are transcribed from the noncoding parts of the genome can be classified into three classes: housekeeping RNAs, transfer RNAs, and regulatory RNAs. MicroRNAs (miRNAs) are a kind of small regulatory RNAs and are approximately consist of 22 nucleotides [1, 2]. RNA polymerase II transcripts these single-stranded RNAs from DNA, then they get processed in the nucleus and after moving to cytoplasm, their maturation starts [3]. MiRNAs after completing

\footnotetext{
*Correspondence: shchaichian@gmail.com; asemi_r@yahoo.com ${ }^{2}$ Research Center for Biochemistry and Nutrition in Metabolic Diseases, Kashan University of Medical Sciences, Kashan, Islamic Republic of Iran ${ }^{4}$ Pars Advanced and Minimally Invasive Medical Manners Research Center, Pars Hospital, Iran University of Medical Sciences, Tehran, Iran Full list of author information is available at the end of the article
}

the maturation process by Dicer (RNase III) [4], bind to some proteins and produce a ribonucleoprotein complex which is involved in silencing the genes and because of that it's called RNA-induced silencing complex (RISC) [2]. miRNA binds to the $3^{\prime}$ untranslated region of the target mRNA and takes its part as a down-regulator for gene expression by inhibiting the starting of translation or by deterioration of mRNA [5]. Because of this important function of miRNAs', they are involved in some crucial processes including: maintenance of stem cells, developmental timing, metabolism, the interaction between a virus and its host, apoptosis, proliferation of the cardiac and skeletal muscular cells and expression of the genes related to neuronal system $[6,7]$.

Every month through the menstrual period, endometrium gets prepared for the implantation of embryo by the means of bearing a class of biological alterations.

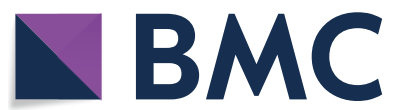

(c) The Author(s) 2020. This article is licensed under a Creative Commons Attribution 4.0 International License, which permits use, sharing, adaptation, distribution and reproduction in any medium or format, as long as you give appropriate credit to the original author(s) and the source, provide a link to the Creative Commons licence, and indicate if changes were made. The images or other third party material in this article are included in the article's Creative Commons licence, unless indicated otherwise in a credit line to the material. If material is not included in the article's Creative Commons licence and your intended use is not permitted by statutory regulation or exceeds the permitted use, you will need to obtain permission directly from the copyright holder. To view a copy of this licence, visit http://creativeco mmons.org/licenses/by/4.0/. The Creative Commons Public Domain Dedication waiver (http://creativecommons.org/publicdomain/ zero/1.0/) applies to the data made available in this article, unless otherwise stated in a credit line to the data. 
Inflammatory reactions, programmed cell death, proliferation of the cells, angiogenesis, tissue formation or differentiation, and remodeling of the tissues are some examples of the engaged processes in altering the endometrium. These processes are regulated by two elements: sex steroids secreted from ovaries and products of the expression of the local genes. There are also some other regulators which their secretion can be autocrine or paracrine and include several growth factors, cytokines, chemokines, proteases, and extracellular matrix [8-11]. Because of the precise expression of this significant regulators, any disturbance can cause an improper regeneration in the endometrium tissue and this may lead to some other abnormalities such as endometriosis [8].

Endometriosis is a condition known by ectopic endometrial glands and stroma which has a dependency to estrogen and is counted as an inflammatory disorder. These ectopic glands and stroma are frequently found in pelvis but there are some other locations in which they have been observed: the bowel, diaphragm, umbilicus, and pleural cavity.

According to evidence, three subtypes are observed for endometriosis: superficial injuries in peritoneal area, deep penetrating wounds, and cysts or endometriomas which are consist of blood and endometrium-like tissue [12]. Dysmenorrhea, pelvic pain, urinary tract symptoms, and rectal bleeding are some symptoms by which endometriosis is diagnosed [13]. Endometriosis, by dint of hormonal induction, stimulation of neural pathways, inflammatory processes, and local bleeding, is able to cause pain but the exact mechanisms are not clear [12]. One of the most important causes of endometriosis is infertility. According to the researches, $25-50 \%$ of women with infertility are diagnosed with endometriosis and also $30-50 \%$ of women with endometriosis are estimated to be infertile [14]. It is also worth to mention that some studies declared that some of the lesions caused by endometriosis, especially the ovarian ones, appear to be monoclonal and being monoclonal is commonly known as a hallmark for neoplasia [15]. Therefore, endometriosis, because of its unfavorable impacts on quality of life, work productivity, and fertility status, is an important disorder among the women in reproductive age [16]. In this review we gathered a great amount of evidence to inquire into the role of micro RNAs in inducing apoptosis and how this mechanism can be exerted for therapeutic purposes for endometriosis.

\section{Endometriosis pathogenesis}

Generally, we put the name of endometriosis on an inflammatory estrogen-dependent condition in which endometrial-like tissues are found in some places other than its real position. Till now, scientists have not come to an agreement about the mechanism by which this condition is caused [17]. Some researchers have come up with some theories such as retrograde menstruation, coelomic metaplasia, and genetic alterations but still, further investigations are needed for clarifying the exact mechanisms. Observing the volume of blood and fragments of endometrial tissue which is refluxed during a menstrual period in women with endometriosis led to the retrograde menstruation theory. According to this theory, these retreated endometrial fragments can be implanted into some other site than uterine and then grow into an ectopic endometrial-type tissue [18-20]. In another theory, the reason of this ectopic tissue's production is mainly attributed to metaplasia of the coelomic epithelium which itself is caused by environmental factors. As well, some scientists believe that the anatomical position of uterine, lymphatic or hematogenous spread of endometrial-related cells, and some other factors such as proton irradiation and dioxin might play a role in pathogenesis of endometriosis [21].

In the immunity point of view, there is also a theory regarding the role of deficient immunity in endometriosis. Haptoglobin and monocyte chemoattractant protein 1 are two agents that might take part in causing endometriosis. In addition, some evidence accounts the abnormal B cell, T cells, or natural killer cells as the responsible factor for this gynecological disease. Moreover, inflammation caused by increased amounts of prostaglandins and cytokines is another possible reason that causes endometriosis $[17,18]$.

In addition, Arvanitis et al. [22] showed the relationship between CYP1A1, CYP19, GSTM1, and GSTT1 polymorphisms and endometriosis.

\section{Apoptosis: a caspase-dependent process}

Generally, programmed cell death or PCD was first separated from apoptosis when necrosis was discovered as another pattern for cell death in early 1970s [23]. Apoptosis is an active exclusive molecular process which is essential in animals with a great number of cells and helps them to regulate the size of their tissues by modulating the number of their cells and also keeps them protected from the cells which can be threats to their homeostasis [24]. Any alteration in the mechanism of apoptosis can cause a complication: Hyper activation of apoptosis leads to some conditions like neurodegenerative diseases, deficiency of the immune system, and ischemia-reperfusion injury and also the suppression of apoptosis can result in some other conditions including cancer, and autoimmune diseases [25].

A group of considerable morphological and biochemical alterations happen through this process and thereby cells first shrink and their nuclei condense, and then they 
disintegrate into well-enclosed apoptotic bodies [26]. In a simple model, three phases can be named for apoptosis: initiation by two different mechanisms, genetic regulation by pro and anti-apoptotic genes, and effector mechanisms by caspases [27]. Commonly, there are two mechanisms that initiate apoptosis: extrinsic and intrinsic pathway. These two pathways are dependent to a group of homogeneous cysteine proteases named caspase family. Caspases are cell-killer proteases and till now, 10 different kinds of them are discovered [28-30].

In the intrinsic pathway, two groups of mitochondrial proteins enter the cytosol in response to stimuli such as hypoxia, free radicals, and radiation. The first group of these proteins causes activation in the caspase-dependent mitochondrial pathway which leads to the activation of caspase-9. The other group causes a fragmentation and a condensation in the DNA and peripheral chromatin of the nuclei, respectively [29, 31-33]. The extrinsic pathway, despite the intrinsic one, what stimulates the process is a ligand and therefore this pathway is dependent to some receptors named death receptors. After the attachment of some ligand such as FasL, TNF, and TRAIL to the death receptors, a death signal is sent to the intracellular pathways and causes the formation and activation of a death-inducing signaling complex or DISC and caspase-8, respectively [33-36]. In the second phase, a motif of gene expression is created through a diversity of mechanisms by the initiators. There are two kinds of these expressed genes: pro-apoptotic (death genes) and anti-apoptotic (survival genes). Two major protein families expressed by these genes are BCL- 2 and p53 families. The BCL-2 is a family of proteins which has more than 20 members and includes both survival and death proteins $[37,38]$. The most known genes of this family are BCL-2 itself, Bim, and the gene BAX which are respectively, anti-apoptotic, pro-apoptotic, and pro-apoptotic [39, 40].

\section{MicroRNAs and apoptosis}

As mentioned before, miRNAs are small evolutionary conserved RNAs which are able to alter the gene expression by affecting the gene's related mRNA [5]. It is estimated that miRNAs are responsible for more than $60 \%$ of gene regulations (coding genes). As well, these RNAs are able to suppress or induce apoptosis by altering its regulatory genes and thus take part in both intrinsic and extrinsic pathways. MiRNAs can influencing the gene expression in two ways: affecting mRNAs directly or indirectly by affecting other miRNAs [41, 42]. In extrinsic pathway, some miRNAs are reported to alter the expression of related ligands. For example, miR-21 is able to directly inhibit FasL and increase apoptosis or miR-130a is able to decrease the TRAIL resistance by the means of affecting some other miRNAs and augment apoptosis $[43,44]$.

Because of the important role of p53 and BCL-2 families in regulating the intrinsic pathway, miRNAs can impact intrinsic pathway by changing the expression of the proteins of this two families [42]. Accumulating evidence demonstrates that more than 20 kinds of miRNAs are directly regulating the pro-apoptotic p 53 gene by binding to the $3^{\prime}$ untranslated region of its mRNA. For instance, one of these miRNAs which can be produced by cancer cells is miR-504. These miRNA binds to two sites of the $3^{\prime}$-UTR region of p53 mRNA and therefore, causes the down-regulation of this gene [38, 45, 46]. Additionally, miRNAs can also take part in changing the expression of apoptotic caspases such as caspase- 9 and caspase- 3 which are blocked by miR-23a and miR-421, respectively $[47,48]$. Therefore, miRNAs are involved in almost all the phases of apoptosis and are able to reduce or induce a cell's apoptosis by influencing intrinsic pathway, extrinsic pathway, and cascades. On the other hand, miRNAs can be used for diagnosis and treatment of many diseases such as cancer and even for prevention of some diseases (according to their potential for pathogenesis).

\section{Apoptosis and endometrium: normal status}

We can name three stages for the cycle of endometrium in menstruating women: proliferating, secretory, and menstrual stages [49]. The presence of apoptosis has been detected (in great extents) in the late secretory, menstrual, and (in very low extents) proliferative and early secretory stages [50-52]. Considering the role of estrogen and progestin in different phases of this cycle, creates this idea that they also have a part in regulating the apoptosis process. Vaskivuo et al. [53] showed that in the proliferative stage, there is an association between the concentration of estradiol in serum and down-regulation of apoptosis. Another involved factor in regulating the apoptosis during the phases of endometrial cycle is the BCL-2 protein produced from its gene. In endometrium, glandular and stromal cells express BCL-2 [54]. Otsuki et al. [55] revealed that during the proliferating time, BCL-2 holds back the apoptosis and hence, it's increased at the end of the first phase and reduced through the late secretory and menstrual stages. In spite of the expression amounts of BCL-2 in glandular cells, consistent immunoreactivity of this gene was observed in smooth muscles of the myometrium layer of the uterine [56]. This evidence demonstrates that the product of BCL- 2 gene not only protects the glandular cells of endometrium but it also is important in the survival of smooth muscles of myometrium. In addition, Rogers et al. found that basal layer of the endometrium, in spite of the functional layer, shows more expression of BCL-2 gene and it's because this layer 
should be constant through the endometrial cycle. They also revealed that steroid hormones are one of the effective factors on altering the BCL-2 expression [57].

There also some other members of the BCL-2 protein family that studies has showed their impact on up or down-regulating the apoptosis in the different layers of endometrium during the endometrial cycle: BAX [51], BCL-X [58], and BAK [59]. These mentioned proteins do their duty in mechanisms which are dependent or independent from the action of BCL-2 [60]. All this together, these data insinuate that there is a dynamic cooperation among a considerable number of members of the BCL-2 family which leads to initiation of apoptosis [60] and ovarian steroids may have a part in apoptosis by controlling the expression of this members of BCL-2 family [55]. Another piece of machinery that is engaged in managing the apoptosis is Fas/FasL system. Fas is a member of TNF/nerve growth factor receptor family which has $45 \mathrm{kDa}$ weight and is counted as a type I protein of the cell membrane [61]. FasL is the ligand of the Fas protein and is a $37 \mathrm{kDa}$ protein. The interaction of Fas and its ligand is a key to the induction of apoptosis [62]. In the course of late proliferative stage, these proteins are being conserved in the Golgi apparatus and cytoplasmic vesicles but they are not able to interact; while in the second phase their release turns on the apoptosis [63]. Membrane-bound and soluble are two kinds of FasLs. Some matrix metalloproteinases or MMP turn the first type into second type which is the active form [64]. In the endometrium, augmented function of MMPs before and throughout the menstruating stage (type 1,3 , and 9) [65] and during the secretory phase [66]. Moreover, BCL-2 also has a role in managing the Fas/FasL related apoptosis: BCL-2 inactivates an enzyme called interleukin-converting enzyme or ICE and thereby inhibits this pathway of apoptosis [67].

\section{Apoptosis and endometrium: abnormal status of endometriosis}

In endometriosis, not only the ectopic endometriumlike tissue goes through a bunch of alterations but the eutopic endometrium also have some differences with the normal one [60]. These differences are consist of a diversity of abnormalities in structure, cell proliferation, immune elements, proteolytic enzymes and their inhibitors, production of steroids and cytokines and proteins, and expression of different genes [68]. These differences can be a factor in the survival of the regurgitating endometrial cells into the peritoneal cavity and thus help the progression of endometriosis [60]. Recently, the presence of apoptosis detected in women with endometriosis has been significantly considered. The number of entered survival cells into the peritoneal cavity is increased in these women because of the reduced amounts of apoptosis during the late secretory/menstrual and early proliferative stages [69]. Expression of the proteins of the BCL-2 family and Fas proteins are the probable factors responsible for diminution of apoptosis in this disorder. Watanabe et al. [54] compared the eutopic and ectopic endometrial tissues in women with endometriosis and found that in spite of the ectopic tissue, expression of BCL-2 has a cyclic pattern in glandular cells of the eutopic tissue. Jones et al. [70] also observed an overexpression of BCL-2 in stroma cells of the ectopic tissues (which might be related to the augmented number of estrogen receptors of the stromal cells [71]). Another research conducted by Meresman et al. [72] manifested that in the first phase of apoptosis expression of BCL-2 and BAX are respectively elevated and absent and BAX is also overexpressed in the second phase in women with this disease compared to the healthy ones (Fig. 1).

We did not found any study comparing the expression of Fas in women with and without disease but a plenty of studies showed that the expression of FasL is higher in women having the disease [73]. Furthermore, some growth factors released from macrophages like plateletderived growth factor (PDGF) and transforming growth factor (TGF) are observed in peritoneal fluid of ill women more than disease-free women. These two growth factors stimulate stromal cells to express more FasL, thus, peritoneal macrophages also contribute to increase the apoptosis of immune cells. It means that ectopic endometroic cells express more FasL to protect themselves against the $\mathrm{T}$ cells of immune system [74, 75]. Additionally, higher extents of MMPs have been seen in sick women who can have a hand in decreasing the immune attacks by T lymphocytes of the host [76-78]. Another observed increased agent in the women with endometriosis is IL-8 which is a chemokine inducing the stromal cell's proliferation and thereby aids the endometroic tissue to grow. Selam et al. [79, 80] found that IL-8, as well, is instrumental in elevating the immunotolerance by the means of stimulating production of FasL. In addition to all of that, even the expression of BCL-2 and BAX is changed in peritoneal macrophages during the endometriosis and so the process of apoptosis is delayed and resistance of disease to immune system is increased [70, 81]. All this considered, apoptosis is a key player in pathophysiology of endometriosis.

\section{MicroRNA and endometriosis: apoptotic activities}

As mentioned before, miRNAs are able to affect apoptosis in many ways: they can regulate each step of apoptosis in both stimulatory and inhibitory manners. As a result, not only miRNAs are involved in the pathogenesis of several diseases but they also have the potential of 


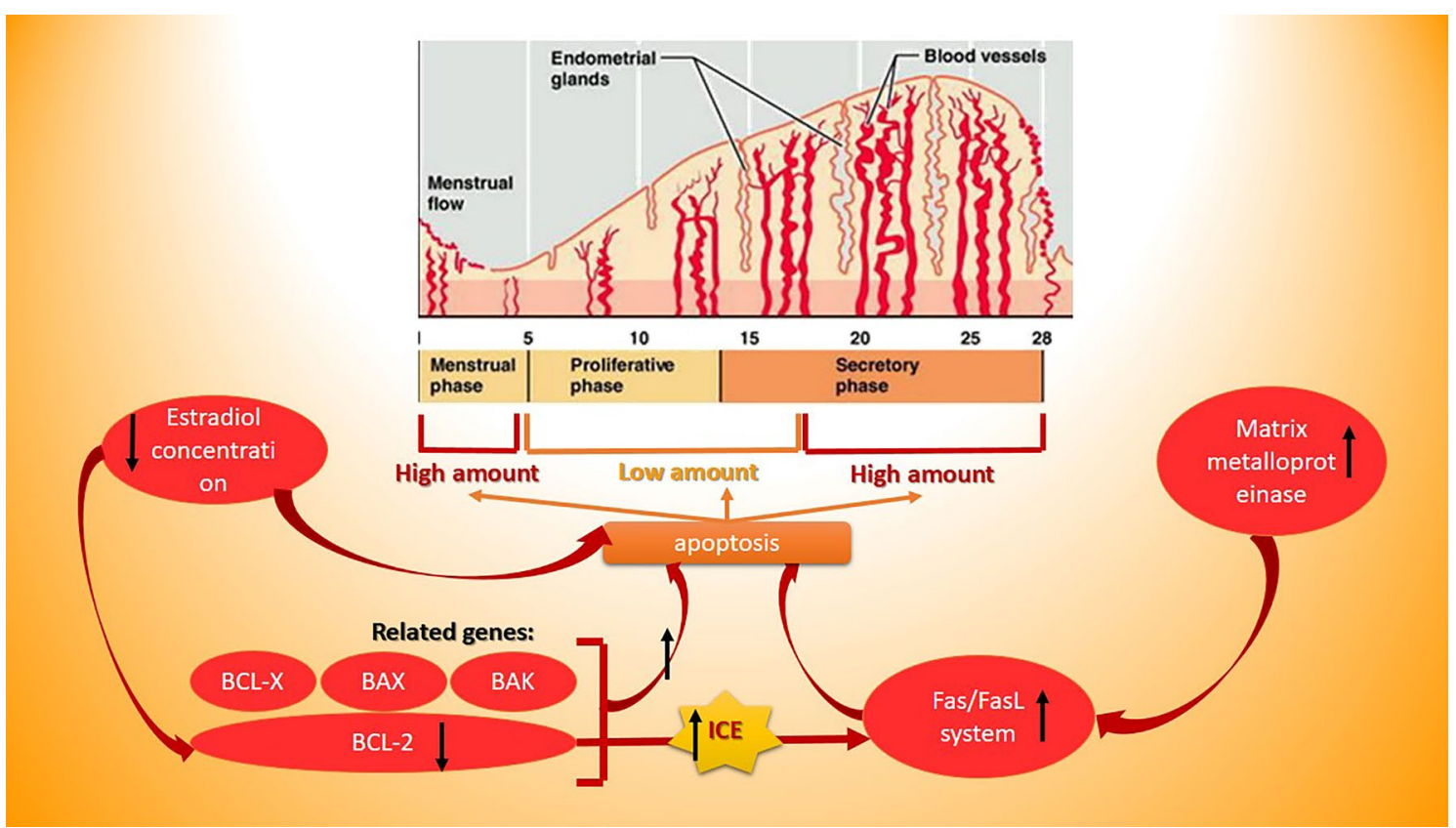

Fig. 1 Endometriosis and related factors and miRNAs

being used as biomarkers or therapeutic targets. Considering the pivotal role of apoptosis in endometriosis, we suggest that these RNAs might start a revolution in our understanding of endometriosis pathogenesis and help us provide more efficient diagnostic and therapeutic procedures. Several kinds of research are conducted about different miRNAs involved in endometriosis by regulating apoptosis which we are going to represent some of them in this section.

Zhang et al. [82] investigated the role of miR-141-3p in endometriosis and demonstrate that this miRNA is down-regulated in ectopic endometrium. MiR-141-3p is one of many miRNAs which affects apoptosis by reducing and inducing the expression of BCL-2 and Bax, respectively. This means that not only this miRNA can be considered as a pathogenesis-related factor but it also can be used as a biomarker and a therapeutic target for endometriosis. MiR-9 is another miRNA that is able to target the BCL-2 mRNA and thereby induce apoptosis. Dysregulation of this miRNA has been observed in some other gynecological diseases like ovarian cancer, as well. According to the down-regulation of this miRNA in endometriosis, Burney and colleagues suggest that this miRNA is somehow related to endometriosis pathogenesis [83]. Similarly, there are some other miRNAs (summarized in Table 1) which their association to endometriosis has been examined and therefore, they have given us a new insight for the pathogenesis of this diseases. Furthermore, they are capable of taking part in treatment of endometriosis by targeting the oncogene mRNAs or by being the target of anti-cancer drugs.

\section{MicoRNA and endometriosis: where are we standing?}

Considering the differences existing between the expressed miRNAs of eutopic and ectopic endometrial tissue, miRNAs have the potential to be used as biomarkers in endometriosis [84]. A study showed that in endometriosis cases, miR-34c-5p, miR-9, miR-34b are down regulated in comparison to normal cases [83]. In addition, miR-483-5p and miR-629-3p are also two other miRNAs which their dysregulation in endometriosis has been confirmed [85]. Moreover, there are also several other miRNAs which are related to angiogenesis, inflammatory, cell proliferation, Steroidogenesis, and other mechanisms engaged in endometriosis and are being used as efficient biomarkers for the endometriosis diagnosis [84, 86-88]. However, involved miRNAs in apoptosis are not considered well in the field of diagnosis and thus, we suggest that investigating the efficacy of some miRNAs such as miR-21, miR-155, and miR-a125b is needed.

In treatment point of view, there are some studies that used miRNAs for targeting different genes and signaling pathways engaged in apoptosis. for instance, adammek et al. [89] tried on miR-145 on eutopic and ectopic endometrial stroma cells and found it useful. Another trial used miR-10b to target syndecan-1 to reduce the 
Table 1 Experimental studies that investigated the role of miRNAs involved in regulating apoptosis in endometriosis

\begin{tabular}{|c|c|c|c|c|}
\hline microRNA & Expression & Function & Application & References \\
\hline $\operatorname{miR}-33 b$ & Down-regulated & Facilitating caspase 3 activity & Treatment and biomarker & {$[96]$} \\
\hline miR-191 & Up-regulated & $\begin{array}{l}\text { Inhibition of TNF-alpha induced apoptosis and might contribute malignant } \\
\text { transformation of endometriosis }\end{array}$ & Treatment and biomarker & {$[97]$} \\
\hline miR-503 & Down-regulated & Targeting BCL-2 mRNAs & Treatment and biomarker & {$[98]$} \\
\hline miR-183 & Down-regulated & Reducing apoptosis & Treatment and biomarker & [99] \\
\hline miR-29c & Down-regulated & Targeting c-JUN (a protein which regulates gene expression) & Treatment and biomarker & {$[100]$} \\
\hline $\operatorname{miR}-148 a$ & - & $\begin{array}{l}\text { Affecting BCL-2 expression and caspase-3/9 through G protein coupled estro- } \\
\text { gen receptor/miR148a/human leukocyte antigen G signaling pathway }\end{array}$ & Treatment & {$[101]$} \\
\hline $\operatorname{miR}-210$ & Up-regulated & $\begin{array}{l}\text { Inhibition of apoptosis by targeting signal transducer and activator of tran- } \\
\text { scription } 3\end{array}$ & Treatment and biomarker & {$[102]$} \\
\hline miR-196b & - & Affecting BCL-2 expression, activation of caspase-3 and caspase-7 & Treatment & {$[103]$} \\
\hline miR-363 & Down-regulated & Inducing apoptosis & Treatment and biomarker & {$[104]$} \\
\hline miR-21-5p & - & Affecting the apoptotic potential of stromal cells. & Treatment & {$[92]$} \\
\hline miR-9 & Down-regulated & Affecting $B C L-2$ expression & Treatment and biomarker & {$[83]$} \\
\hline miR181c & - & NR4A-miR181c-Mst1 pathway regulates mitochondrial apoptosis & Treatment & {$[105]$} \\
\hline miR-2861 & Down-regulated & Up-regulation of STAT3 and MMP2 and inducing apoptosis & Treatment and biomarker & {$[106]$} \\
\hline miR-141-3p & - & $\begin{array}{l}\text { Down-regulation the expression of } \mathrm{Bcl}-2 \text { and raising the expression of Bax } \\
\text { and contributing to the apoptosis of ectopic ESCs }\end{array}$ & Treatment & {$[82]$} \\
\hline
\end{tabular}

cell invasiveness and observed considerable results [90]. As well, some other studies used miRNA such as $\mathrm{miR}-135 \mathrm{a} / \mathrm{b}$ as therapeutic targets to treat the infertility caused by endometriosis [91]. There is also another trial that examined saponin, a component of Korean red ginseng, and found that it can target miR-21-5p and thereby be a therapeutic tool for endometriosis [92].

Notwithstanding all these evidence, there are still some obstacles in the way of using miRNAs as a common treatment for endometriosis. Low stability and potential side effects are two major limitations of using these RNAs. Furthermore, the lack of proper route of administration and delivering approaches are some other barriers which nanotechnology is removing them out of the way by providing novel delivery systems [93]. All taken together, there is a lot of room in the field of using miRNAs for diagnosis and treatment of endometriosis for further investigations.

\section{Conclusions}

For years, scientists thought that $98 \%$ of our DNA was junk and not useful at all [94] but discoveries about the functions of RNAs transcribed from the non-coding parts of DNA made a revolution in our therapeutic and diagnostic approaches for many diseases. miRNAs are a kind of small non-coding RNAs which are known to have many parts in cellular processes (including apoptosis, cell proliferation, and inflammation) by regulating the gene expression. Hence, their contribution in pathogenesis of many diseases such as endometriosis is proven. Endometriosis is a gynecological disorder among the women in reproductive age that might lead to cancer (in a very low percentage of women) and is also an important disease for causing several health problems such as infertility. Accumulative evidence has demonstrated the role of cell proliferation, apoptosis, and invasion in the progression of these diseases. In this review, we looked into the specific role of apoptosis and its related genes and pathways in endometriosis and tied to present an explanation of how miRNAs can affect endometriosis by their apoptotic activities. What we found is that many miRNAs are involved and they are responsible for repressing apoptosis and progression of the disease. As a result, these miRNAs have the potential to be used in diagnostic and therapeutic decisions adopted for endometriosis. In the field of diagnosis, the current gold standard method for endometriosis is using surgery (laparoscopy) and direct observation [95]. Hence, miRNAs have the potential to be an ideal replacement for this dangerous and high-risk approach and plus, they can act more efficient for early detection of endometriosis. Although considering the many roles and functions that miRNAs have in cellular pathways, more investigations are needed for revealing their side effects after administration. Furthermore, finding proper delivery systems which are able to increase the stability of miRNAs, protect them against degradation inside the body, and deliver them to the specific site of the disease are needed.

\section{Abbreviations}

miRNA: microRNA; RISC: RNA-induced silencing complex; PDGF: Plateletderived growth factor; TGF: Transforming growth factor; PCD: Programmed 
cell death; TNF: Tumor necrosis factor; MMP: Matrix metalloproteinase; ICE: Interleukin converting enzyme; DAPK1: Death-associated protein kinase 1.

\section{Acknowledgements}

Not applicable.

\section{Authors' contributions}

MT, FS, HM, BY, BM, SC, MAM and ZA contributed in data collection and manuscript drafting. All authors approved the final version for submission. ZA oversaw the study. All authors read and approved the final manuscript.

\section{Funding}

Not applicable.

\section{Availability of data and materials}

Not applicable.

\section{Ethics approval and consent to participate}

Not applicable.

\section{Consent for publication}

Not applicable.

\section{Competing interests}

The authors declare no competing interests.

\section{Author details}

1 Department of Gynecology and Obstetrics, Ramsar Campus, Mazandaran University of Medical Sciences, Sari, Iran. ${ }^{2}$ Research Center for Biochemistry and Nutrition in Metabolic Diseases, Kashan University of Medical Sciences, Kashan, Islamic Republic of Iran. ${ }^{3}$ Stem Cell Research Center, Tabriz University of Medical Sciences, Tabriz, Iran. ${ }^{4}$ Pars Advanced and Minimally Invasive Medical Manners Research Center, Pars Hospital, Iran University of Medical Sciences, Tehran, Iran. ${ }^{5}$ Department of Epidemiology and Biostatistics, School of Public Health, Tehran University of Medical Sciences, Tehran, Iran.

Received: 12 November 2019 Accepted: 30 January 2020 Published online: 11 February 2020

\section{References}

1. Chen H, Xu Z, Liu D. Small non-coding RNA and colorectal cancer. J Cell Mol Med. 2019;23:3050-7.

2. Hu W, Coller J. What comes first: translational repression or mRNA degradation? The deepening mystery of microRNA function. Cell Res. 2012;22:1322.

3. Bartel DP. MicroRNAs: genomics, biogenesis, mechanism, and function. Cell. 2004;116:281-97.

4. Hutvágner G, McLachlan J, Pasquinelli AE, Bálint É, Tuschl T, Zamore PD. A cellular function for the RNA-interference enzyme Dicer in the maturation of the let-7 small temporal RNA. Science. 2001;293:834-8.

5. Liu J, Carmell MA, Rivas FV, Marsden CG, Thomson JM, Song J-J, et al. Argonaute2 is the catalytic engine of mammalian RNAi. Science. 2004;305:1437-41.

6. Xu C, Lu Y, Pan Z, Chu W, Luo X, Lin H, et al. The muscle-specific microRNAs miR-1 and miR-133 produce opposing effects on apoptosis by targeting HSP60, HSP70 and caspase-9 in cardiomyocytes. J Cell Sci. 2007;120:3045-52.

7. Kim J, Inoue K, Ishii J, Vanti WB, Voronov SV, Murchison E, et al. A MicroRNA feedback circuit in midbrain dopamine neurons. Science. 2007;317:1220-4.

8. Pan Q, Chegini N. MicroRNA signature and regulatory functions in the endometrium during normal and disease states. Semin Reprod Med. 2008;26:479-93.

9. Jabbour HN, Kelly RW, Fraser HM, Critchley HO. Endocrine regulation of menstruation. Endocr Rev. 2006;27:17-46.

10. Achache H, Revel A. Endometrial receptivity markers, the journey to successful embryo implantation. Hum Reprod Update. 2006;12:731-46.

11. Lim KJ, Odukoya OA, Ajjan RA, Li T-C, Weetman AP, Cooke ID. The role of T-helper cytokines in human reproduction. Fertil Steril. 2000;73:136-42.
12. Hickey M, Ballard K, Farquhar C. Endometriosis. BMJ. 2014;348:g1752.

13. Ballard K, Seaman H, Vries CS, Wright J. Can symptomatology help in the diagnosis of endometriosis? Findings from a national case-control stud. BLOG. 2008;115:1382-91.

14. Macer ML, Taylor HS. Endometriosis and infertility: a review of the pathogenesis and treatment of endometriosis-associated infertility. Obstetr Gynecol Clin. 2012;39:535-49.

15. Matias-Guiu X, Stewart CJR. Endometriosis-associated ovarian neoplasia. Pathology. 2018;50:190-204.

16. Simoens S, Dunselman G, Dirksen C, Hummelshoj L, Bokor A, Brandes I, et al. The burden of endometriosis: costs and quality of life of women with endometriosis and treated in referral centres. Hum Reprod. 2012;27:1292-9.

17. Vercellini P, Viganò P, Somigliana E, Fedele L. Endometriosis: pathogenesis and treatment. Nat Rev Endocrinol. 2014;10:261.

18. Baldi A, Campioni M, Signorile PG. Endometriosis: pathogenesis, diagnosis, therapy and association with cancer. Oncol Rep. 2008;19:843-6.

19. Burney RO, Giudice LC. Pathogenesis and pathophysiology of endometriosis. Fertil Steril. 2012;98:511-9.

20. Sasson IE, Taylor HS. Stem cells and the pathogenesis of endometriosis. Ann NY Acad Sci. 2008;1127:106.

21. Witz CA. Pathogenesis of endometriosis. Gynecol Obstet Invest. 2002;53:52-62.

22. Arvanitis DA, Koumantakis GE, Goumenou AG, Matalliotakis IM, Koumantakis EE, Spandidos DA. CYP1A1, CYP19, and GSTM1 polymorphisms increase the risk of endometriosis. Fertil Steril. 2003;79:702-9.

23. Kerr JF, Wyllie AH, Currie AR. Apoptosis: a basic biological phenomenon with wideranging implications in tissue kinetics. Br J Cancer. 1972;26:239.

24. Hengartner MO. The biochemistry of apoptosis. Nature. 2000;407:770-6.

25. Thompson CB. Apoptosis in the pathogenesis and treatment of disease. Science. 1995;267:1456-62.

26. Majno G, Joris I. Apoptosis, oncosis, and necrosis. An overview of cell death. Am J Pathol. 1995;146:3.

27. Renehan AG, Bach SP, Potten CS. The relevance of apoptosis for cellular homeostasis and tumorogenesis in the intestine. Can J Gastroenterol Hepatol. 2001;15:166-76.

28. Cohen GM. Caspases: the executioners of apoptosis. Biochem J. 1997;326:1-16.

29. Elmore S. Apoptosis: a review of programmed cell death. Toxicol Pathol. 2007;35:495-516.

30. Alnemri ES, Livingston DJ, Nicholson DW, Salvesen G, Thornberry NA, Wong WW, et al. Human ICE/CED-3 protease nomenclature. Cell. 1996;87:171.

31. Saelens X, Festjens N, Vande Walle L, van Gurp M, van Loo G, Vandenabeele P. Toxic proteins released from mitochondria in cell death. Oncogene. 2004;23:2861-74.

32. Du C, Fang M, Li Y, Li L, Wang X. Smac, a mitochondrial protein that promotes cytochrome c-dependent caspase activation by eliminating IAP inhibition. Cell. 2000;102:33-42.

33. Reed JC. Mechanisms of apoptosis. Am J Pathol. 2000;157:1415-30.

34. Wajant $\mathrm{H}$. The Fas signaling pathway: more than a paradigm. Science. 2002;296:1635-6.

35. Chen G, Goeddel DV. TNF-R1 signaling: a beautiful pathway. Science. 2002;296:1634-5.

36. Fleisher TA. Apoptosis. Ann Allergy Asthma Immunol. 1997;78:245-9.

37. Renehan AG, Booth C, Potten CS. What is apoptosis, and why is it important? BMJ. 2001;322:1536-8.

38. Liu J, Zhang C, Zhao Y, Feng Z. MicroRNA Control of p53. J Cell Biochem. 2017:118:7-14.

39. Sjostrom J, Bergh J. How apoptosis is regulated, and what goes wrong in cancer. BMJ. 2001;322:1538-9.

40. Cory S, Adams JM. The Bcl2 family: regulators of the cellular life-ordeath switch. Nat Rev Cancer. 2002;2:647.

41. Friedman RC, Farh KK-H, Burge CB, Bartel DP. Most mammalian mRNAs are conserved targets of microRNAs. Genome Res. 2009;19:92-105.

42. Kiraz Y, Adan A, Yandim MK, Baran Y. Major apoptotic mechanisms and genes involved in apoptosis. Tumor Biol. 2016;37:8471-86.

43. Acunzo M, Visone R, Romano G, Veronese A, Lovat F, Palmieri D, et al. miR-130a targets MET and induces TRAIL-sensitivity in NSCLC by downregulating miR-221 and 222. Oncogene. 2012;31:634. 
44. Wang P, Zhuang L, Zhang J, Fan J, Luo J, Chen H, et al. The serum miR21 level serves as a predictor for the chemosensitivity of advanced pancreatic cancer, and miR-21 expression confers chemoresistance by targeting FasL. Mol Oncol. 2013;7:334-45.

45. Hu W, Chan CS, Wu R, Zhang C, Sun Y, Song JS, et al. Negative regulation of tumor suppressor $\mathrm{p} 53$ by microRNA miR-504. Mol Cell. 2010;38:689-99.

46. Hermeking H. MicroRNAs in the p53 network: micromanagement of tumour suppression. Nat Rev Cancer. 2012;12:613.

47. Shang J, Yang F, Wang Y, Wang Y, Xue G, Mei Q, et al. MicroRNA-23a antisense enhances 5-fluorouracil chemosensitivity through APAF-1/ caspase-9 apoptotic pathway in colorectal cancer cells. J Cell Biochem. 2014:115:772-84.

48. Wu J-H, Yao Y-L, Gu T, Wang Z-Y, Pu X-Y, Sun W-W, et al. MiR-421 regulates apoptosis of BGC-823 gastric cancer cells by targeting caspase-3. Asian Pac J Cancer Prev. 2014;15:5463-8.

49. Wood DH, Levison D. Atrophy and apoptosis in the cyclical human endometrium. J Pathol. 1976;119:159-66.

50. Shikone T, Yamoto M, Kokawa K, Yamashita K, Nishimori K, Nakano R. Apoptosis of human corpora lutea during cyclic luteal regression and early pregnancy. J Clin Endocrinol Metab. 1996;81:2376-80.

51. Tao X-J, Tilly Kl, Maravei DV, Shifren JL, Krajewski S, Reed JC, et al. Differential expression of members of the bcl-2 gene family in proliferative and secretory human endometrium: glandular epithelial cell apoptosis is associated with increased expression of bax. J Clin Endocrinol Metab. 1997:82:2738-46.

52. Kokawa K, Shikone T, Nakano R. Apoptosis in the human uterine endometrium during the menstrual cycle. J Clin Endocrinol Metab. 1996;81:4144-7.

53. Vaskivuo T, Stenbäck F, Karhumaa P, Risteli J, Dunkel L, Tapanainen JS. Apoptosis and apoptosis-related proteins in human endometrium. Mol Cell Endocrinol. 2000;165:75-83.

54. Watanabe $H$, Kanzaki $H$, Narukawa $\mathrm{S}$, Inoue $T$, Katsuragawa $H$, Kaneko $\mathrm{Y}$, et al. BCl-2 and Fas expression in eutopic and ectopic human endometrium during the menstrual cycle in relation to endometrial cell apoptosis. Am J Obstet Gynecol. 1997;176:360-8.

55. Otsuki Y, Ito Y, Akao Y, Misaki O, Sugimoto O, Tsujimoto Y. Cyclic bcl-2 gene expression in human uterine endometrium during menstrual cycle. Lancet. 1994;344:27-9.

56. Daikoku E, Ito Y, Otsuki Y. The induction of apoptosis in ovaries and uteri ofbcl-2-deficient mice. Med Electr Microsc. 1998;31:68-76.

57. Rogers PA, Lederman F, Plunkett D, Affandi B. BCl-2, Fas and caspase 3 expression in endometrium from levonorgestrel implant users with and without breakthrough bleeding. Hum Reprod. 2000;15:152-61.

58. Boise LH, González-García M, Postema CE, Ding L, Lindsten T, Turka LA, et al. BCl-x, a bcl-2-related gene that functions as a dominant regulator of apoptotic cell death. Cell. 1993;74:597-608.

59. Tao X-J, Sayegh RA, Tilly JL, Isaacson KB. Elevated expression of the proapoptotic $B C L-2$ family member, BAK, in the human endometrium coincident with apoptosis during the secretory phase of the cycle. Fertil Steril. 1998;70:338-43.

60. Harada T, Kaponis A, Iwabe T, Taniguchi F, Makrydimas G, Sofikitis N, et al. Apoptosis in human endometrium and endometriosis. Hum Reprod Update. 2004;10:29-38.

61. Nagata S, Golstein P. The Fas death factor. Science. 1995;267:1449-56.

62. Suda T, Okazaki T, Naito Y, Yokota T, Arai N, Ozaki S, et al. Expression of the Fas ligand in cells of T cell lineage. J Immunol. 1995;154:3806-13.

63. Song J, Rutherford T, Naftolin F, Brown S, Mor G. Hormonal regulation of apoptosis and the Fas and Fas ligand system in human endometrial cells. Mol Hum Reprod. 2002;8:447-55.

64. Tanaka M, Suda T, Haze K, Nakamura N, Sato K, Kimura F, et al. Fas ligand in human serum. Nat Med. 1996;2:317.

65. Salamonsen L, Woolley D. Matrix metalloproteinases in normal menstruation. Hum Reprod. 1996;11:124-33.

66. Enari M, Hase A, Nagata S. Apoptosis by a cytosolic extract from Fasactivated cells. EMBO J. 1995;14:5201-8.

67. Shimizu S, Eguchi Y, Kamiike W, Matsuda H, Tsujimoto Y. Bcl-2 expression prevents activation of the ICE protease cascade. Oncogene. 1996;12:2251-7.

68. Sharpe-Timms KL. Endometrial anomalies in women with endometriosis. Ann N Y Acad Sci. 2001;943:131-47.
69. Gebel HM, Braun DP, Tambur A, Frame D, Rana N, Dmowski WP. Spontaneous apoptosis of endometrial tissue is impaired in women with endometriosis. Fertil Steril. 1998;69:1042-7.

70. Jones RK, Searle RF, Bulmer JN. Apoptosis and bcl-2 expression in normal human endometrium, endometriosis and adenomyosis. Hum Reprod. 1998;13:3496-502.

71. Fujishita A, Nakane PK, Koji T, Masuzaki H, Chavez RO, Yamabe T, et al. Expression of estrogen and progesterone receptors in endometrium and peritoneal endometriosis: an immunohistochemical and in situ hybridization study. Fertil Steril. 1997;67:856-64.

72. Meresman GF, Vighi S, Buquet RA, Contreras-Ortiz O, Tesone M, Rumi LS. Apoptosis and expression of $\mathrm{BCl}-2$ and $\mathrm{Bax}$ in eutopic endometrium from women with endometriosis. Fertil Steril. 2000;74:760-6.

73. Garcia-Velasco JA, Mulayim N, Kayisli UA, Arici A. Elevated soluble Fas ligand levels may suggest a role for apoptosis in women with endometriosis. Fertil Steril. 2002;78:855-9.

74. Oosterlynck DJ, Meuleman C, Waer M, Koninckx PR. Transforming growth factor-beta activity is increased in peritoneal fluid from women with endometriosis. Obstet Gynecol. 1994;83:287-92.

75. Garcia-Velasco JA, Arici A, ZreikT, Naftolin F, Mor G. Macrophage derived growth factors m odulate Fas ligand expression in cultured endometrial stromal cells: a role in endometriosis. Mol Hum Reprod. 1999;5:642-50.

76. Gearing A, Beckett P, Christodoulou M, Churchill M, Clements J, Davidson $A$, et al. Processing of tumour necrosis factor-a precursor by metalloproteinases. Nature. 1994;370:555.

77. Kayagaki N, Kawasaki A, Ebata T, Ohmoto H, Ikeda S, Inoue S, et al. Metalloproteinase-mediated release of human Fas ligand. J Exp Med. 1995;182:1777-83.

78. Ueda M, Yamashita Y, Takehara M, Terai Y, Kumagai K, Ueki K, et al. Survivin gene expression in endometriosis. J Clin Endocrinol Metab. 2002;87:3452-9.

79. Iwabe T, Harada T, Tsudo T, Tanikawa M, Onohara Y, Terakawa N. Pathogenetic significance of increased levels of interleukin-8 in the peritoneal fluid of patients with endometriosis. Fertil Steril. 1998;69:924-30.

80. Selam B, Kayisli UA, Garcia-Velasco JA, Akbas GE, Arici A. Regulation of fas ligand expression by IL-8 in human endometrium. J Clin Endocrinol Metab. 2002;87:3921-7.

81. McLaren J, Prentice A, Charnock-Jones D, Sharkey A, Smith S. Immunolocalization of the apoptosis regulating proteins $\mathrm{BCl}-2$ and Bax in human endometrium and isolated peritoneal fluid macrophages in endometriosis. Hum Reprod. 1997;12:146-52.

82. Zhang Y, Yan J, Pan X. miR-141-3p affects apoptosis and migration of endometrial stromal cells by targeting KLF-12. Pflugers Arch. 2019:471:1055-63.

83. Burney RO, Hamilton AE, Aghajanova L, Vo KC, Nezhat CN, Lessey BA, et al. MicroRNA expression profiling of eutopic secretory endometrium in women with versus without endometriosis. Mol Hum Reprod. 2009;15:625-31.

84. Mari-Alexandre J, Sanchez-Izquierdo D, Gilabert-Estelles J, BarceloMolina M, Braza-Boils A, Sandoval J. miRNAs regulation and its role as biomarkers in endometriosis. Int J Mol Sci. 2016;17:93. https://doi. org/10.3390/ijms17010093.

85. Laudanski P, Charkiewicz R, Kuzmicki M, Szamatowicz J, Charkiewicz A, Niklinski J. MicroRNAs expression profiling of eutopic proliferative endometrium in women with ovarian endometriosis. Reprod Biol Endocrinol. 2013;11:78.

86. Mari-Alexandre J, Garcia-Oms J, Barcelo-Molina M, Gilabert-Aguilar J, Estelles A, Braza-Boils A, et al. MicroRNAs and angiogenesis in endometriosis. Thromb Res. 2015;135(Suppl 1):S38-40.

87. Coutinho LM, Ferreira MC, Rocha ALL, Carneiro MM, Reis FM. New biomarkers in endometriosis. Adv Clin Chem. 2019;89:59-77.

88. Ahn SH, Singh V, Tayade C. Biomarkers in endometriosis: challenges and opportunities. Fertil Steril. 2017;107:523-32.

89. Adammek M, Greve B, Kässens N, Schneider C, Brüggemann K, Schüring AN, et al. MicroRNA miR-145 inhibits proliferation, invasiveness, and stem cell phenotype of an in vitro endometriosis model by targeting multiple cytoskeletal elements and pluripotency factors. Fertil Steril. 2013;99(1346-55):e5.

90. Schneider C, Kässens N, Greve B, Hassan H, Schüring AN, StarzinskiPowitz A, et al. Targeting of syndecan-1 by micro-ribonucleic acid miR$10 \mathrm{~b}$ modulates invasiveness of endometriotic cells via dysregulation 
of the proteolytic milieu and interleukin-6 secretion. Fertil Steril. 2013;99(871-81):e1.

91. Petracco R, Grechukhina O, Popkhadze S, Massasa E, Zhou Y, Taylor HS. MicroRNA 135 regulates HOXA10 expression in endometriosis. J Clin Endocrinol Metab. 2011;96:E1925-33.

92. Park JH, Lee SK, Kim MK, Lee JH, Yun BH, Park JH, et al. Saponin extracts induced apoptosis of endometrial cells from women with endometriosis through modulation of miR-21-5p. Reprod Sci. 2018;25:292-301.

93. Panir K, Schjenken JE, Robertson SA, Hull ML. Non-coding RNAs in endometriosis: a narrative review. Hum Reprod Update. 2018;24:497-515.

94. Watson CN, Belli A, Di Pietro V. Small non-coding RNAs: new class of biomarkers and potential therapeutic targets in neurodegenerative disease. Front Genet. 2019;10:364.

95. Santamaria X, Taylor H. MicroRNA and gynecological reproductive diseases. Fertil Steril. 2014;101:1545-51.

96. Yang WW, Hong L, Xu XX, Wang Q, Huang JL, Jiang L. Regulation of miR$33 \mathrm{~b}$ on endometriosis and expression of related factors. Eur Rev Med Pharmacol Sci. 2017;21:2027-33.

97. Tian X, Xu L, Wang P. MiR-191 inhibits TNF-alpha induced apoptosis of ovarian endometriosis and endometrioid carcinoma cells by targeting DAPK1. Int J Clin Exp Pathol. 2015;8:4933-42.

98. Hirakawa T, Nasu K, Abe W, Aoyagi Y, Okamoto M, Kai K, et al. miR-503, a microRNA epigenetically repressed in endometriosis, induces apoptosis and cell-cycle arrest and inhibits cell proliferation, angiogenesis, and contractility of human ovarian endometriotic stromal cells. Hum Reprod. 2016;31:2587-97.

99. Shi XY, Gu L, Chen J, Guo XR, Shi YL. Downregulation of miR-183 inhibits apoptosis and enhances the invasive potential of endometrial stromal cells in endometriosis. Int J Mol Med. 2014;33:59-67.

100. Long M, Wan X, La X, Gong X, Cai X. miR-29c is downregulated in the ectopic endometrium and exerts its effects on endometrial cell proliferation, apoptosis and invasion by targeting c-Jun. Int J Mol Med. 2015;35:1119-25.

101. He SZ, Li J, Bao HC, Wang MM, Wang XR, Huang X, et al. G proteincoupled estrogen receptor/miR148a/human leukocyte antigenG signaling pathway mediates cell apoptosis of ovarian endometriosis. Mol Med Rep. 2018;18:1141-8.

102. Okamoto M, Nasu K, Abe W, Aoyagi Y, Kawano Y, Kai K, et al. Enhanced miR-210 expression promotes the pathogenesis of endometriosis through activation of signal transducer and activator of transcription 3. Hum Reprod. 2015;30:632-41.

103. Abe W, Nasu K, Nakada C, Kawano Y, Moriyama M, Narahara H. miR-196b targets c-myc and Bcl-2 expression, inhibits proliferation and induces apoptosis in endometriotic stromal cells. Hum Reprod. 2013;28:750-61.

104. Li W, Fan X, Zhang M, Huang L, Lv S, Wang L, et al. Systematic analysis of hsa-miR-363 gene overexpression pattern in endometrial stromal cells. Int J Mol Med. 2018;42:2793-800.

105. Zhao Q, Ye M, Yang W, Wang M, Li M, Gu C, et al. Effect of Mst1 on endometriosis apoptosis and migration: role of Drp1-related mitochondrial fission and parkin-required mitophagy. Cell Physiol Biochem. 2018:45:1172-90

106. Yu H, Zhong Q, Xia Y, Li E, Wang S, Ren R. MicroRNA-2861 targets STAT3 and MMP2 to regulate the proliferation and apoptosis of ectopic endometrial cells in endometriosis. Pharmazie. 2019;74:243-9.

\section{Publisher's Note}

Springer Nature remains neutral with regard to jurisdictional claims in published maps and institutional affiliations.
Ready to submit your research? Choose BMC and benefit from:

- fast, convenient online submission

- thorough peer review by experienced researchers in your field

- rapid publication on acceptance

- support for research data, including large and complex data types

- gold Open Access which fosters wider collaboration and increased citations

- maximum visibility for your research: over $100 \mathrm{M}$ website views per year

At BMC, research is always in progress.

Learn more biomedcentral.com/submissions 